\title{
ARCHAEOLOGICAL EVIDENCE FOR HISTORICAL NAVIGATION ON THE MUREŞ (MAROS) RIVER. ENQUIRIES BASED ON A MEDIEVAL BOAT IMPRINT FROM BIZERE ABBEY (ROMANIA)
}

\author{
A. A. RUSU \\ Institute of Archaeology and Art History of the Romanian Academy, M. Kogălniceanu 12-14, R0-400084, \\ Cluj-Napoca \\ aarusu@gmail.com \\ O. TODA \\ Department of History, Archaeology and Museology, "1 December 1918” University, \\ N. Iorga 11-13, RO-510009, Alba Iulia \\ oanatoda@yahoo.com
}

\begin{abstract}
The boat imprint unearthed at the site of the Benedictine abbey from Bizere (Frumuseni, Romania) is a unique discovery for two reasons: its preservation as a negative imprint, due to its reuse for preparing mortar, and its dating back to the $12^{\text {th }}$ century, based on the context of its discovery. It has been identified as a logboat, due to the absence of any technical details specific for plank boats, and now stands as the only vessel of this type with known dating for the territory of Romania. The article also enquires into the wider historical context of the discovery, thus bringing forth the archival data available with regard to medieval inland navigation.

Keywords: inland navigation, medieval boat, water transport, dating, Benedictine abbey
\end{abstract}

The remains of a medieval Benedictine monastic complex ('monasterium de Bisra') 1 are located $15 \mathrm{~km}$ away from the town of Arad (Arad county, Romania) (Fig. 1), near the village of Frumuşeni (GE: Schöndorf), on a former island of the river Mureş (Fig. 2). The monastery functioned between the $12^{\text {th }}$ and $16^{\text {th }}$ centuries. It represents one of the medieval monastic foundations along the lower course of the river Mureş, which aroused scientific interest through its recurring but scanty mention in archival sources. ${ }^{2}$ It was only after the start of systematic archaeological research, that, through ten successive campaigns (between 2001 and 2009), its main architectural and utilitarian features were unearthed (Fig. 3). The series of discoveries culminated with the identification of two fragments of pavement mosaics in 2003. These finds could be attributed artistically to the late Romanesque period displaying phytomorphic, zoomorphic and geometric motifs with possible Byzantine and Adriatic influences. ${ }^{3}$

The attention drawn by early excavation results favoured the continuation of research and the discovery of a series of utilitarian features. ${ }^{4}$ The medieval boat discussed in this article is included among these. It could be identified because of a change in its primary function and its reuse as a lime chest during one of the construction phases, which secured its survival as a negative imprint in the mortar. ${ }^{5}$

\section{CONTEXT OF DISCOVERY AND TECHNICAL DATA}

The traces of the boat were unearthed through prospective investigation, conducted during the archaeological campaign in 2008. The primary aim of prospecting was the examination of the abbey's sector that unfolded

\footnotetext{
${ }^{1}$ WeNZEL 1873: 46-48; DIR.C 1951: 9-10.

${ }^{2}$ BURNICHIOIU 2011: 119-122.

${ }^{3}$ BurnichioIU-Rusu 2011: 3-13.

${ }^{4}$ Rusu 2011a: 49-60; Rusu 2011b: 95-100.
}

DOI: 10.1556/AArch.65.2014.1.6
${ }^{5}$ At the end of the research campaign the mortar imprint was preserved in situ with the financial support of the Arad Museum Complex (CMA). The small finds mentioned in the present study are being stored at the same institution under the indicated inventory numbers.

Acta Archaeologica Academiae Scientiarum Hungaricae 65 (2014) 139-154 0001-5210/\$20.00 (C) 2014 Akadémiai Kiadó, Budapest 


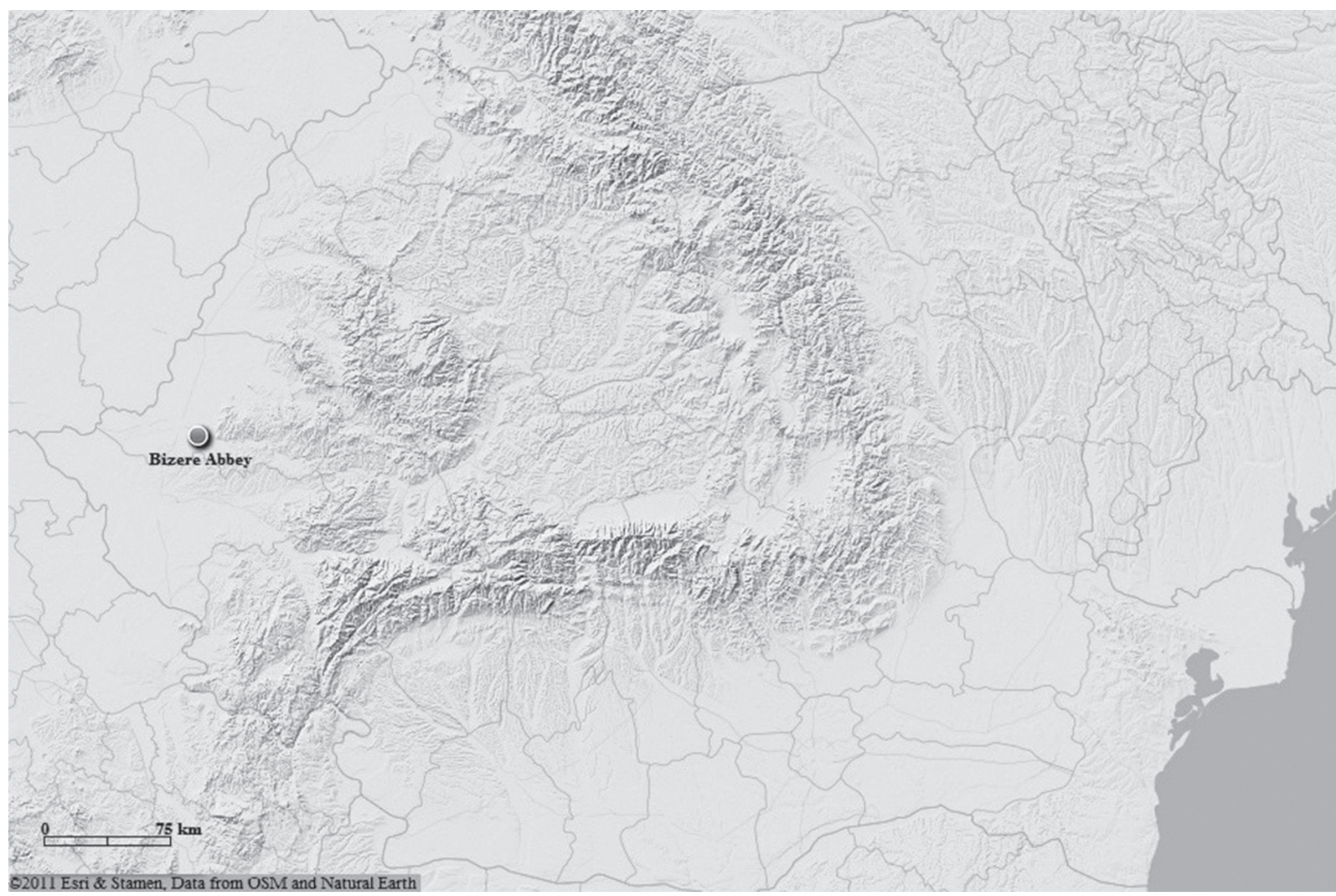

Fig. 1. Geographical location of the Bizere abbey (Frumuşeni, Arad county, Romania)

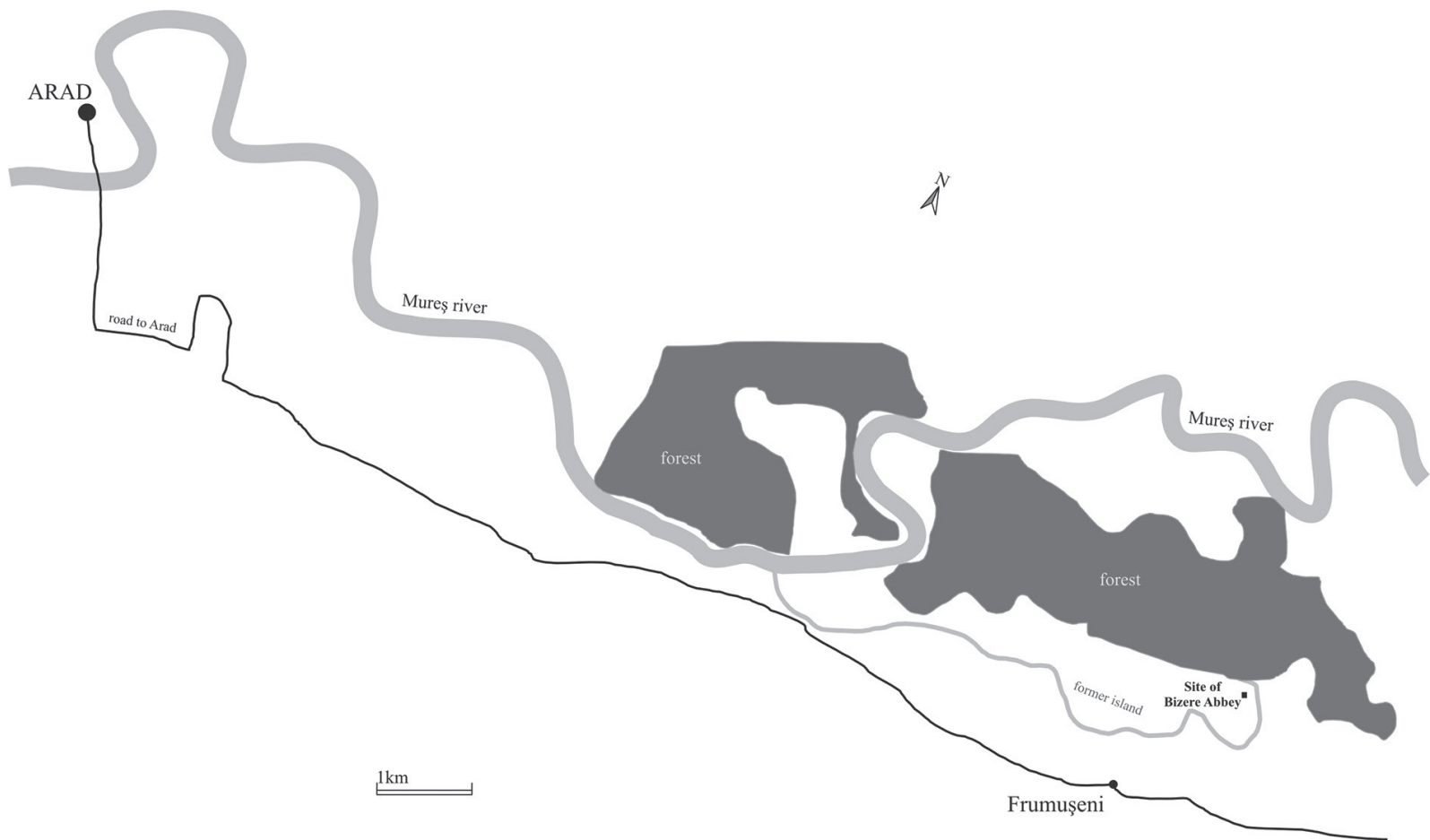

Fig. 2. Location of the archaeological site of Bizere abbey (the authors) 


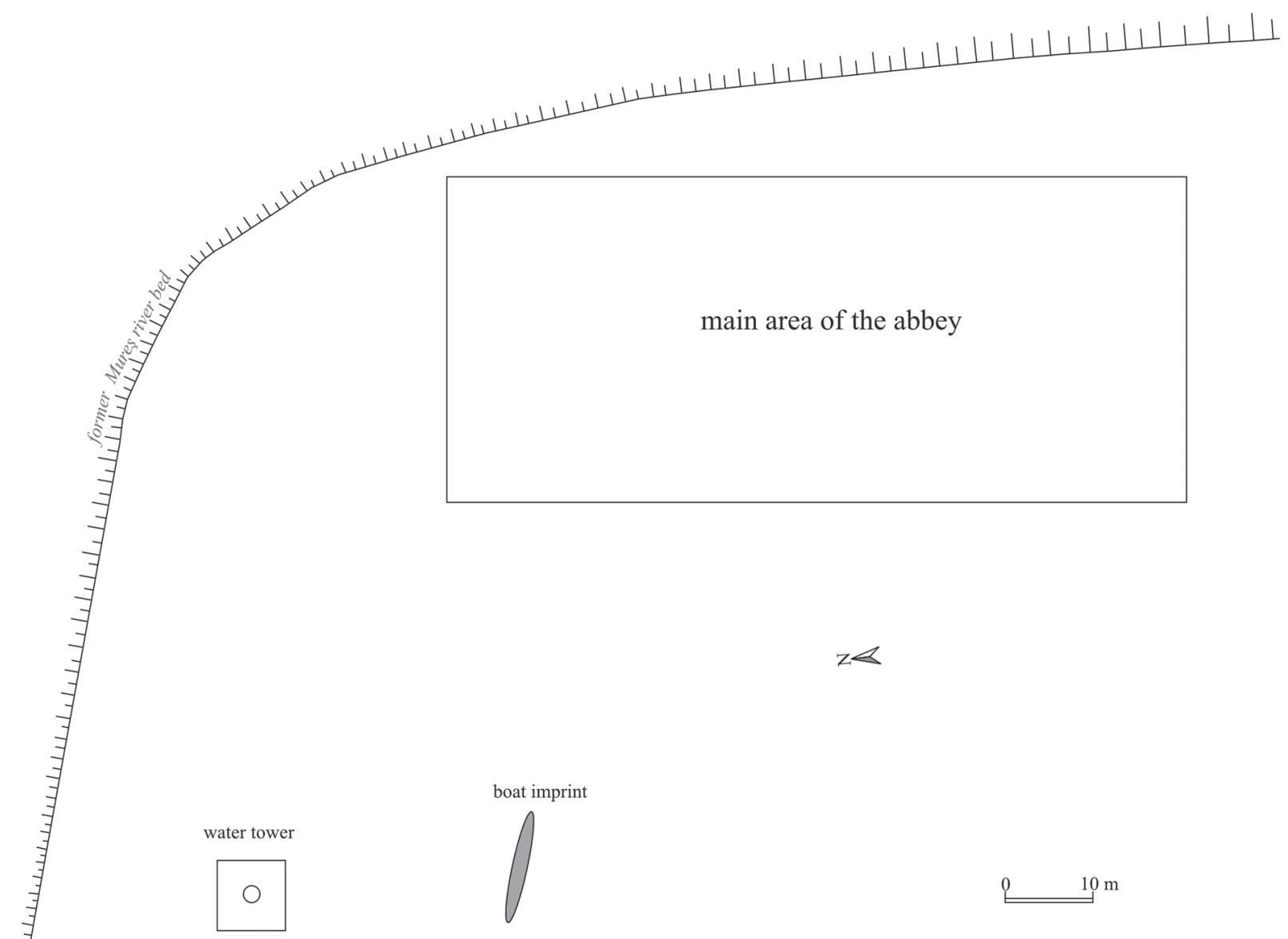

Fig. 3. General ground plan of the abbey (the authors)

south of the water tower, near the middle of the former island (Fig. 4). The flat terrain, with absolute levels ranging between 117.75 and $117.94 \mathrm{~m}$ (above Black Sea level), did not show any anomalies or level changes that could have predicted this discovery.

Thus, the opening of several evaluation trenches $(\mathrm{T})$ along a north-south axis, in order to delineate the spread of the monastic complex in that area, set off with the excavation of T 74/A $(15 \times 1 \mathrm{~m})$, starting $8 \mathrm{~m}$ south of the water tower cavity. ${ }^{6}$ It was followed by T 74/B $(10 \times 1 \mathrm{~m})$ leaving a $1 \mathrm{~m}$ wide unexcavated area between the two. $\mathrm{T} 74 / \mathrm{D}(4 \times 1 \mathrm{~m})$ was inserted between $\mathrm{T} 74 / \mathrm{B}$ and $\mathrm{T} 74 / \mathrm{C}(15 \times 1 \mathrm{~m})$, with $0.50 \mathrm{~m}$ thick unexcavated areas, thus eliminating the $5 \mathrm{~m}$ initial distance left between the two previously investigated trenches. The prospection continued towards the south with T 74/E $(9 \times 1 \mathrm{~m}), \mathrm{T} 74 / \mathrm{F}(10 \times 1 \mathrm{~m})$ and T 74/G $(20 \times 1 \mathrm{~m})$, separated by standard $1 \mathrm{~m}$ wide strips of unexcavated areas (Fig. 5/a).

The negative imprint of the boat was discovered at approximately $30.40 \mathrm{~m}$ south of the water tower cavity. Its outline was identified in the northern half of $\mathrm{T} 74 / \mathrm{B}$ at $2.40 \mathrm{~m}$ from the northern section. The trench transversally cut over one segment of the imprint. After identification, the feature was completely unearthed and studied through collateral trenches T 77, T 77/A opened towards the west, T 82, T 84 and T 84/A towards the east (Fig. 5/a). The first one to be planed was $\mathrm{T} 77(4 \times 3.5 \mathrm{~m})$, aligned to the northern end of the reference trench at a distance of $0.50 \mathrm{~m}$. Additionally, a new trench, T 77/A $(1 \times 1 \mathrm{~m})$, was opened. It ran parallel to the western side of T 77, $1 \mathrm{~m}$ south of the north-western corner of the reference trench. In the area located east of $\mathrm{T} 74 / \mathrm{B}$ new trenches were cut at $2.20 \mathrm{~m}$ south from the north-eastern corner of the initial one. T $82(3 \times 1.90 \mathrm{~m})$ was cut with its long side parallel to T 74/B. One $\mathrm{m}$ 


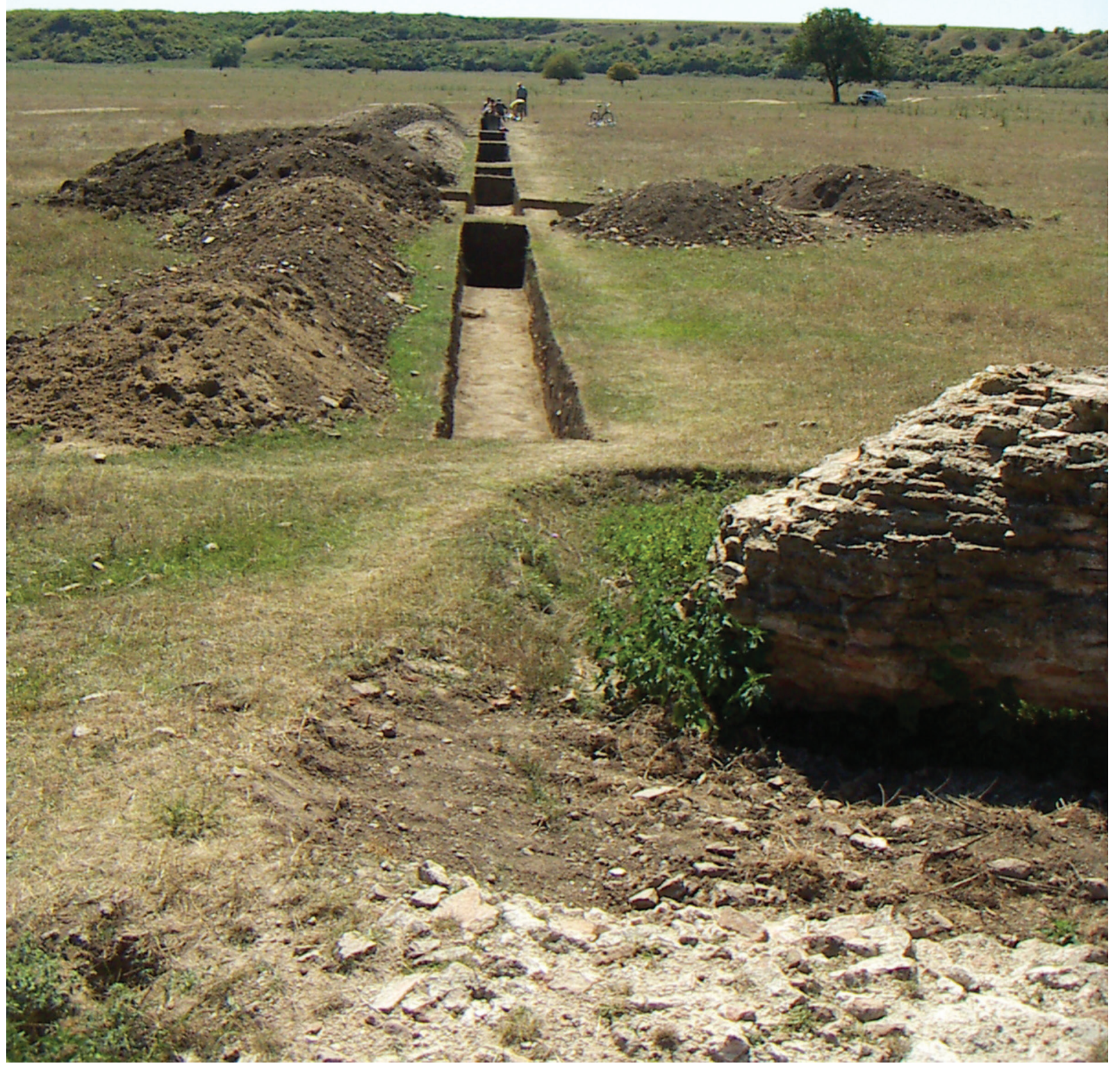

Fig. 4. North-south view of T 74A-G (the authors) 


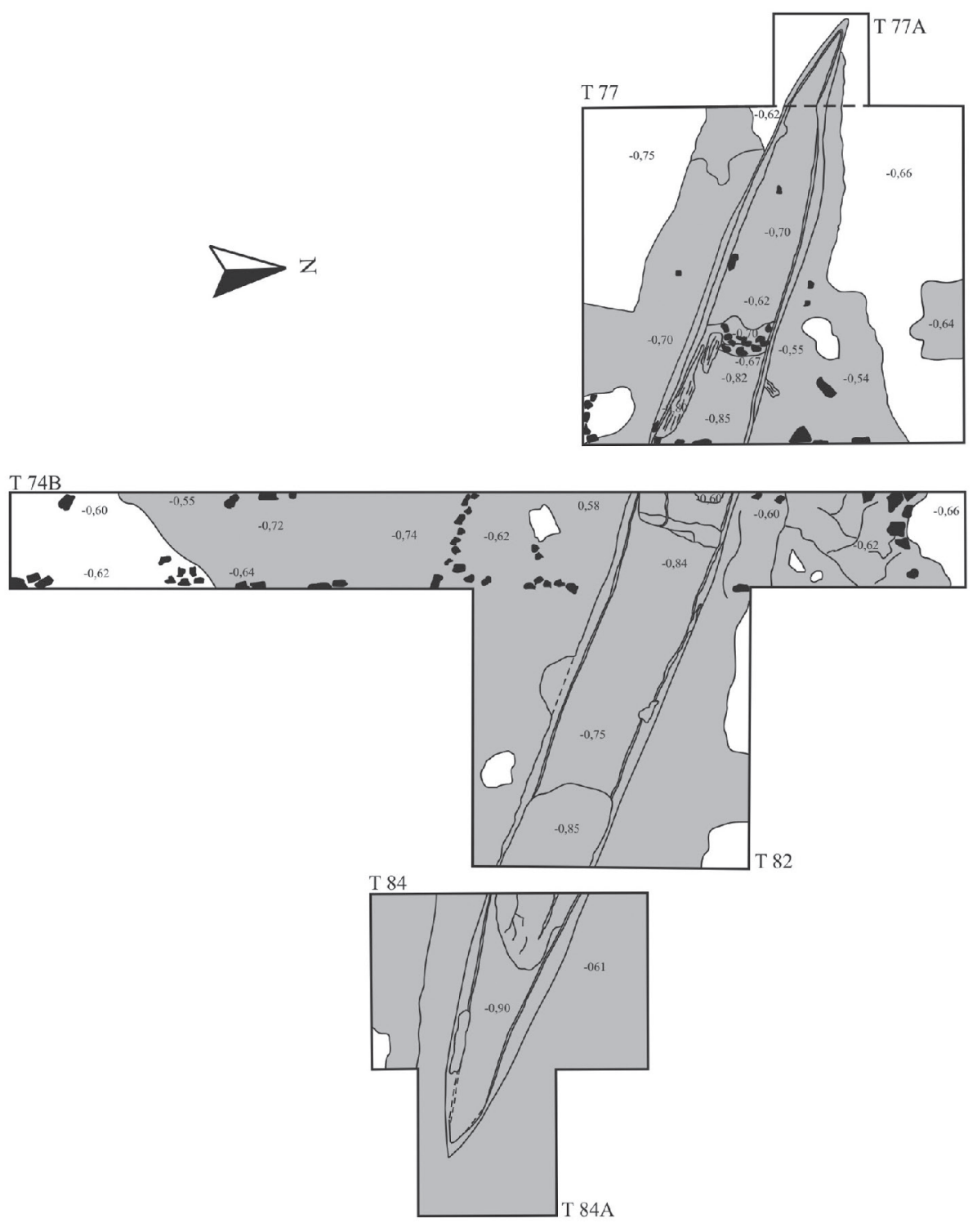

T 74B, western section

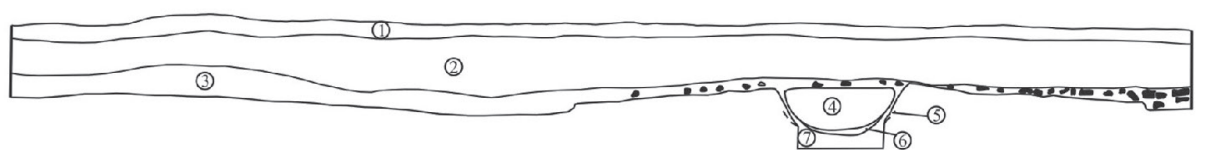

Legend:

(1) topsoil

(2) deposit of earth with mortar and brick detritus

(3) layer of debris with brick fragments

(4) layer of mortar mixed with earth

(5) solidified mortar with brick fragments

(6) solidified mortar without intrusions

(7) geological bed of yellowish sand

$$
\square \text { mortar }
$$$$
\underline{0}+1 \mathrm{~m} \quad \mathrm{~b}
$$

Fig. 5. The boat imprint. a: ground plan; b: western section of T 74B (the authors) 
towards the south from the north-eastern corner of $\mathrm{T} 82$, and after a $0.30 \mathrm{~m}$ wide unexcavated area, $\mathrm{T} 84(3 \times 1.90$ $\mathrm{m})$ and $\mathrm{T} 84 / \mathrm{A}(1.60 \times 1.50 \mathrm{~m})$ were opened. The latter was oriented towards east, $0.50 \mathrm{~m}$ away from the southeastern corner of $\mathrm{T} 84$. In the final phase of field research the intermediate unexcavated areas were partially researched. The entire complex had an extension covering approximately $30 \mathrm{~m}^{2}$. For stratigraphic purposes a $0.20 \mathrm{~m}$ deep cut intersected the inferior part of the imprint in T 74/B. This allowed observation of the boat's middle section.

The stratigraphy of the area proved to be extremely simple and uniform in the first four segments of the control trench T74 (A-D). Beneath the approximately $0.15 \mathrm{~m}$ thick layer of top soil a deposit of $0.40-0.50 \mathrm{~m}$ was identified, the top of which was levelled by tillage in the last century. Debris belonging to the demolition layer of the water tower could be identified in its lower part, consisting of fragmented bricks and mortar pigment. An unambiguous demolition layer was clearly identified underneath formed by an assemblage of bricks and mortar with a constant thickness of between $0.15-0.17 \mathrm{~m}$. Its absence in the vicinity of the tower and its expansion towards the south suggests the existence of another brick construction in close proximity of the boat. This stratigraphic accumulation directly superposed the mortar layer from the area surrounding the imprint. The mortar fill of the former boat reached a maximum thickness of $0.48 \mathrm{~m}$. Beneath the mortar the geological bed of a well-tamped yellow sandy layer was found (Fig. 5/b).

The mortar platform and interior filling preserved the horizontal outline of the side walls (Fig. 6). The hydrodynamic shape, with pointed ends, clearly allows one to identify the artefact as a watercraft. The length of the boat was $12.25 \mathrm{~m}$, and its maximum width was about $1.15-1.20 \mathrm{~m}$. A maximum height of about $0.48 \mathrm{~m}$ was recorded in the middle area. As its general contour shows, the western end was sharper than the other. This is also proven by a measurable difference in degrees of the two angularities: the point toward the west measured $34^{\circ}$, while it was $44^{\circ}$ to the east. Presumably, it can represent a simple deformation caused by degradation. However, most likely, it gives one a means to differentiate between the sharper bow from the more massive stern. Based on the degree of preservation, the cross-section outlines a boat with sloping walls and a slightly curved bottom (Figs 7-8). The walls' thickness was of 3-4 cm (Fig. 9), while the floor measured around $6 \mathrm{~cm}$ in thickness. Apparently none of the structural elements survived. This may suggest their total absence or their deliberate removal at the moment when they became useless and the function of the object changed. As for the finishing of the boat, only slight remains of wood fibre could be noted. Any proof of the existence of some additional components, such as transversal ridges, was completely missing. The building was uniform and, at the time of the object's soaking in mortar, the state of decay was not yet advanced. It has to be mentioned that the position at the time of discovery did not show any visible inclination of the vessel towards either of the two sides. In other words, the vessel was probably well-balanced on the ground surface in order to serve its new purpose.

Towards the southern end of the boat, parallel with its sidewall, traces of an approximately $0.80 \mathrm{~m}$ long and $0.12-0.13 \mathrm{~m}$ wide plank were noted. This imprint showed no signs of bending (Fig. 10). However, unlike the walls of the boat, this piece left visible traces of wood fibre. Its affiliation to the boat and its possible discovery in a secondary position as a result of the artefact's degradation remains questionable. Another explanation would be the use of this fragment for the reinforcement of the boat walls, in a sector where the boat was damaged. A second interior imprint - a semi-circular beam, cut on the shaft $(0.40 \times 0.10 \mathrm{~m})$ - was discovered in the clean mortar found in the western part of the vessel. This also left traces of wood fibres, as did the afore-mentioned plank. It is hard to say whether it belonged to the structure of the boat, since the trace showed no sings of bending. It seems easier to imagine this piece of wood as having been used for stirring or extracting the mortar from the mixing area.

The traces of the bottom and sidewalls were not homogenously preserved, due to the presence of various types of mortar as well as to the differential emptying of the lime basin. Its western third was filled with clean, good quality mortar, which best preserved the sides of the planking (Fig. 8). The outlines were visible for the middle area of the boat but the interior was emptied to the bottom. At the eastern end the vessel was again filled with mortar but of a consistency different from that of the opposite end. It was coarse and it contained brick fragments, therefore the contours were poorly preserved (Fig. 6).

The outline of the hardened mortar platform surrounding the boat was irregular. While at its eastern end that exceeding the boat's perimeter was quite small $(0.40 \mathrm{~m}$ towards south and only maximum $0.20 \mathrm{~m}$ towards north), the surface significantly widened next to the emptied part of the boat. Towards the south, the imprint of the mortar was circular as if it was the result of a natural, unprovoked leakage. Thus, it could be noted that the mortar had seeped to over a meter from where it was prepared. Adding to this observation the different consistency of the 


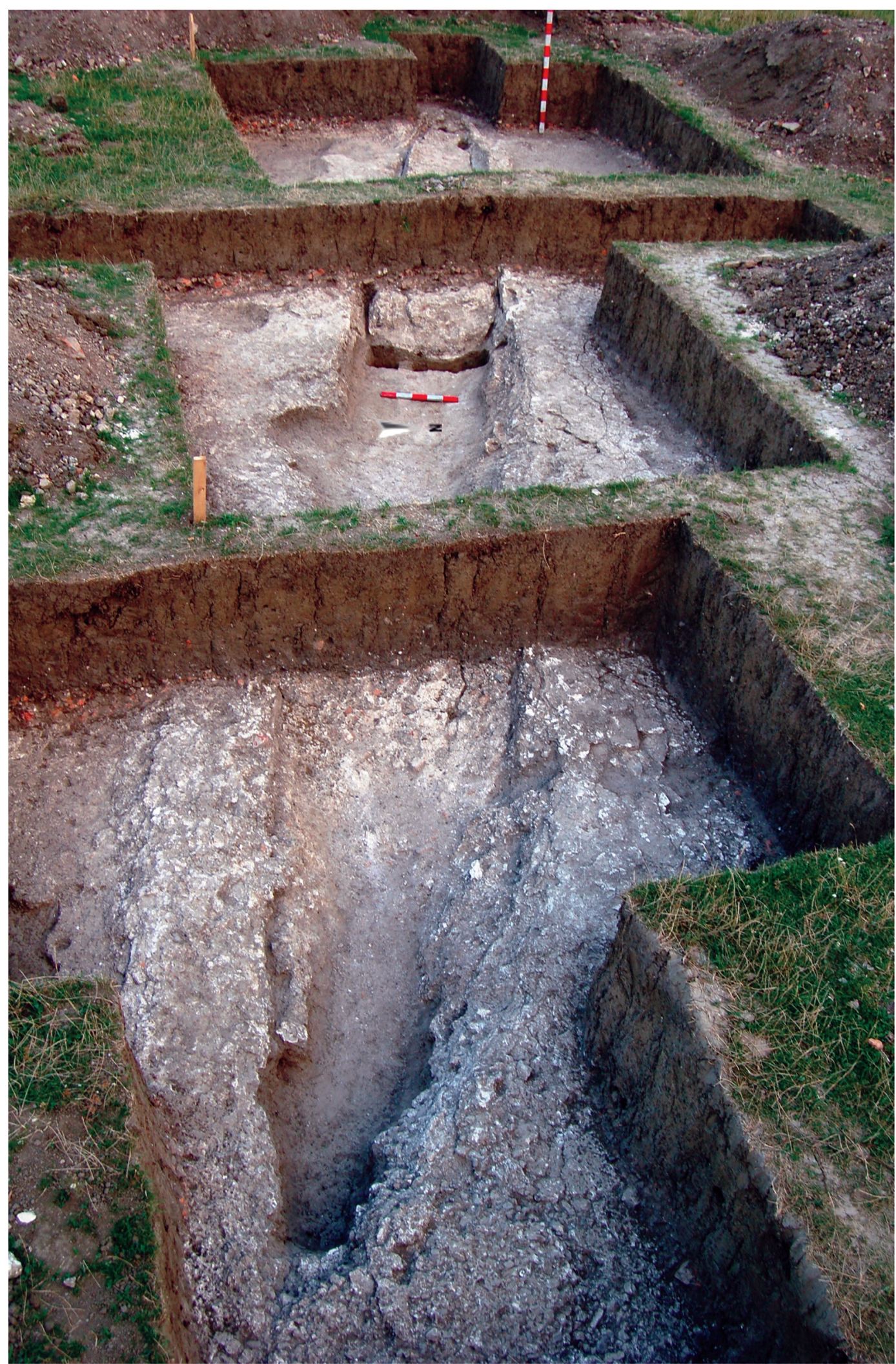

Fig. 6. General view of the boat's imprint (the authors) 


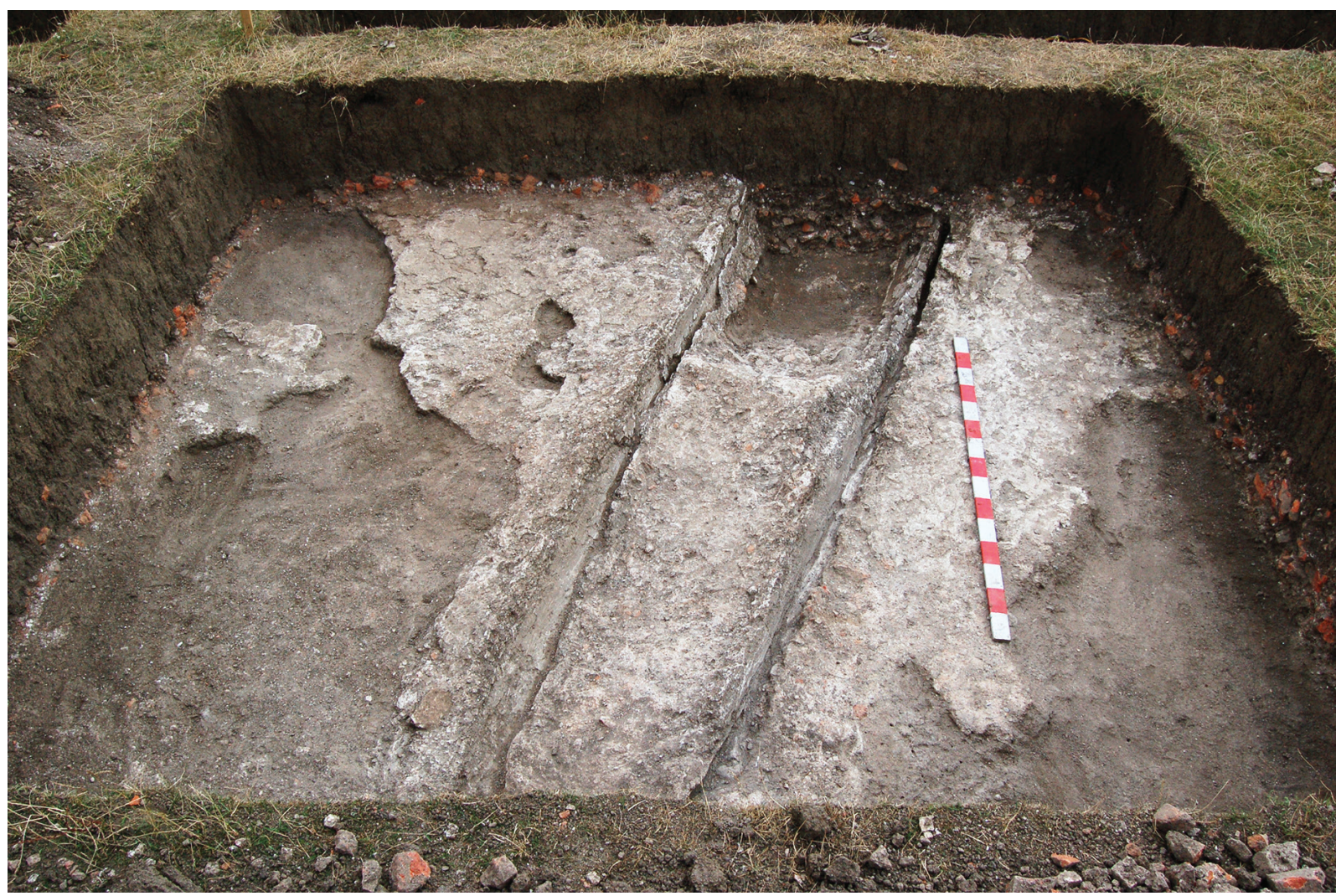

Fig. 7. Detail of the boat's north-western end, western view (the authors)

mortar found in the boat, it can be concluded that it was emptied in sections before it was abandoned. The differing preservation was determined by the fact that only a small part of the boat contained good quality mortar. Still, it cannot be ruled out that the less well-preserved parts of the watercraft had been previously damaged, a reason which could have determined the change in usage. Most probably, it was a boat which could no longer fulfil its primary function; it was decommissioned, pulled ashore and, at a certain point, used as a lime chest. The occasion may have been the building of the water tower (Fig. 3) or of an as yet only presumed brick- or stonework found nearby, towards south-west. ${ }^{7}$ As the surrounding area of the boat indicated, additional structures - such as an improvised construction shed - were not used for the building site. Moreover, when the construction was finished the temporary arrangement of the former boat was abandoned on the spot.

\section{REUSE CONTEXT AND DATING}

The depositions found inside the imprint contained small-sized brick fragments, a little stone material, late Árpád Period pottery and animal bones (mammals, birds, fish). However, other small finds discovered in nearby trenches were conclusive enough to establish the chronological frame of the context, since there was no complication in the stratigraphy or any finds that would have belonged to different historical periods.

The main type of artefact was common pottery specific to the late Árpád Period $\left(12^{\text {th }}-13^{\text {th }}\right.$ centuries). This was present in both demolition layers that superposed the boat imprint. From the various ceramic potsherds uncovered at the site, two pieces are worth mentioning: a glazed fragment, and one with embossed decoration in the shape

${ }^{7}$ As shown by the preliminary results of the geophysical investigations conducted at the site in 2013. 


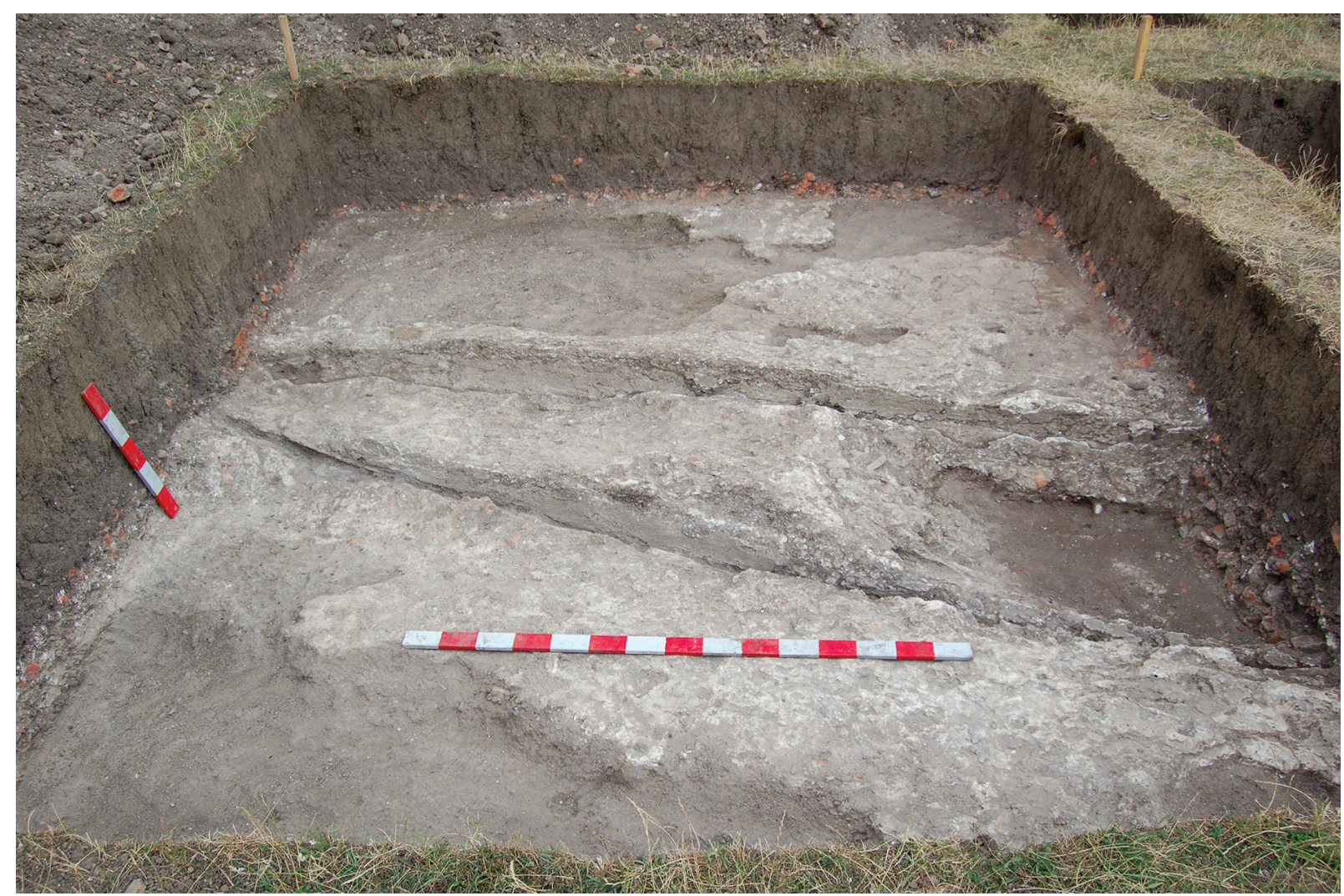

Fig. 8. Detail of the boat's north-western end, southern view (the authors)

of a small fir (T 84). These two were part of a limited series considered to be imported pottery or showing Byzantine influence. ${ }^{8}$ The association between a great number of pottery fragments and animal bones provides additional evidence for the final burial of the reused boat in a deposition layer containing a lot of demolition and refuse material.

The relative dating of the context was based on a concave coin issued by King Stephen IV (1162-1163) ${ }^{9}$ and a spur along with its strap buckle, ${ }^{10}$ dated at the end of the $12^{\text {th }}$ century and beginning of the $13^{\text {th }}$ century. ${ }^{11}$ All artefacts come from the lower demolition layer, overlapping the boat imprint ( $\mathrm{T} 74 / \mathrm{C},-0.50 \mathrm{~m}$, from present ground level). Based on the terminus post quem date set by these small finds, it can be concluded that the reuse of the boat most likely took place during the $12^{\text {th }}$ century. Furthermore, the chronology corresponds to that of the water tower as part of the most extensive construction phase of the monastic site. It preceded the fourth decade of the $13^{\text {th }}$ century, when written sources point to the decaying state of the abbey. ${ }^{12}$

\section{BUILDING TECHNIQUE}

The uneven conservation of the boat as a negative mortar imprint has deprived researchers of valuable details regarding the building technique. The lack of wood fibre imprints made it impossible to determine the type of timber used for construction. Moreover, the preservation of no additional structure details makes it difficult to classify the vessel as a logboat or an assembled structure. Its most obvious traits, such as the pointed ends and the thin sidewalls are usually present in the case of plank-built structures, although they constitute insufficient grounds

${ }^{8}$ RUSU-MARTA 2002: 133-136.

${ }^{9}$ RÉTHY 1899: 6, 98; CMA, inv. no. 17.473 .

${ }^{10} \mathrm{CMA}$, inv. no. 17.474 .
${ }^{11}$ RUTTKAY 1976: 347, 350, fig. 72; IONIȚ Ă 2009: p. 36, pl.

$16 / 24$. 


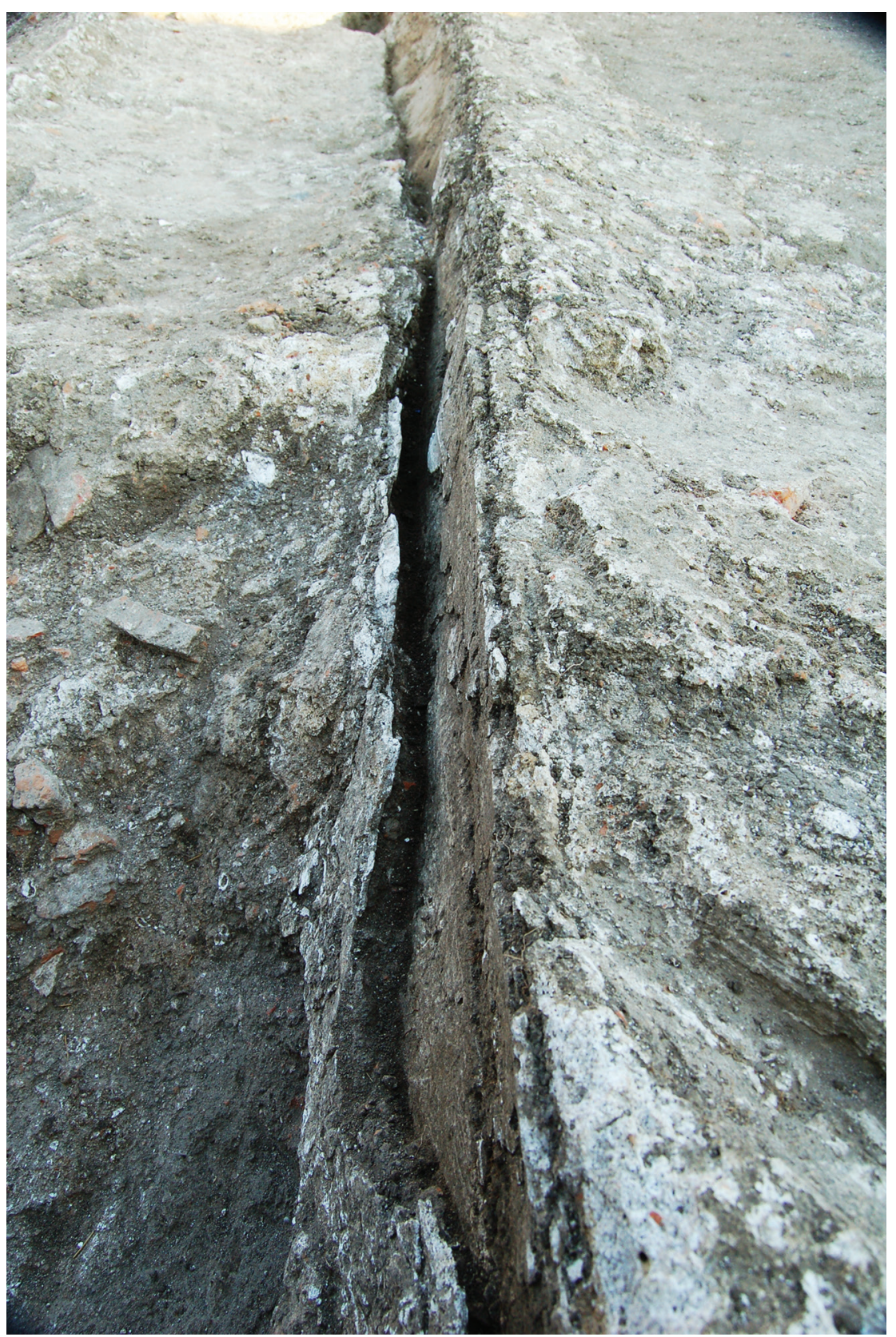

Fig. 9. Detail of the boat's sidewall (the authors)

for identifying it as such a vessel. For example, logboats such as the find from Wakefield (Yorkshire, United Kingdom $)^{13}$ and Hamburg (Germany) $)^{14}$ also have overly-angular V-shaped ends. This type of shaping could have been motivated by the intention of imitating plank boats and not simply by basic principles of hydrodynamics. As for the thin sidewalls, one can bring forth the example of the logboat from Palanca (Prahova county, Romania), with similar values. ${ }^{15}$ Some small plank boats measured even smaller than this. In the case of a vessel discovered in the United Kingdom, the sidewalls were $2 \mathrm{~cm}$ thick in an area where the planks overlapped one another. ${ }^{16}$

\footnotetext{
${ }^{13}$ MCGRaIL 1981: fig. 5.

${ }^{14}$ ARNOLD 1995a: 141.
}

${ }^{15}$ LiCHIADOPOL 2007-2008: 142.

${ }^{16}$ Hutchinson 1994: 124. 


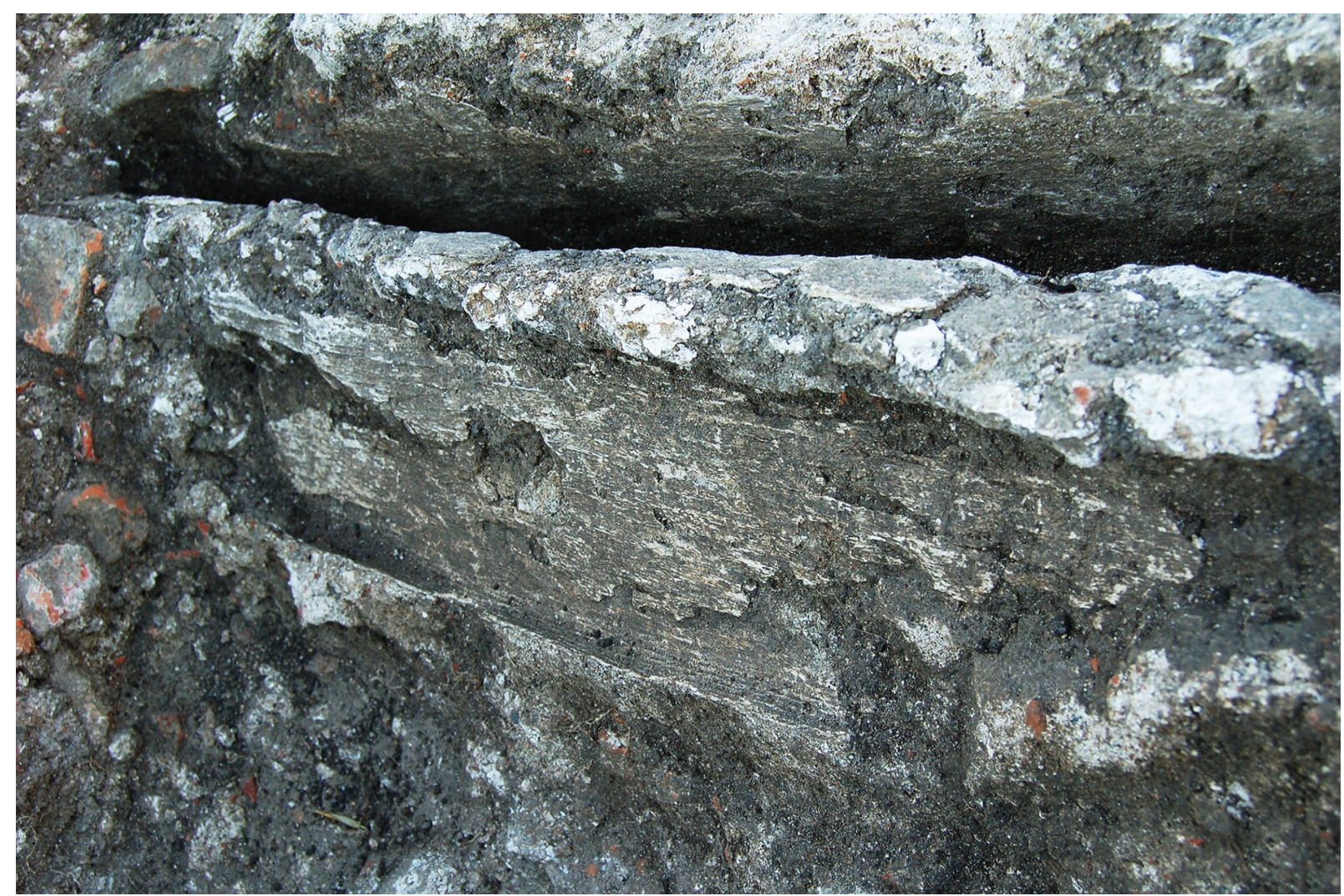

Fig. 10. Detail of the boat's sidewall with preserved wood fibre impressions (the authors)

The discovery of iron or wooden nails or dowels, vital for the joining of various boat components, ${ }^{17}$ would have furnished undeniable evidence for an assembled construction be it a plank boat or an assembled logboat. ${ }^{18}$ The absence of such features or evidence for the overlapping of the planks (the so-called clinker technique) ${ }^{19}$ seems to put aside this interpretation. Furthermore, the degrading or repairs - a rather common practice - of an assembled boat would have left traceable marks in the hardened mortar.

All in all, the present vessel from Bizere abbey can be identified as a possible logboat. Aside from the construction technique, the discovery makes an important contribution to the understanding of the inland navigation from the eastern parts of the medieval kingdom of Hungary.

\section{ANALOGIES}

Any discussion on subjects related to medieval nautical archaeology, according to its western-European definitions, ${ }^{20}$ may appear an unusual approach given the present state of research in Romania. In this territory there is a lack of prospections pertaining to the field of river archaeology. ${ }^{21}$ This is why, so far, all the recorded finds belong to the logboat type and are the result of random discoveries. Eighteen such artefacts were recovered from riverbeds across the country; but, as yet, they do not represent the object of detailed research. Most of them received

${ }^{17}$ POMEY-REITH 2005: 29.

${ }_{18}$ PomeY-Reith 2005: 195-198. The medieval employment of the respective construction technique on the territory of the kingdom of Hungary was certified by the discovery of the presumably medieval vessel from Ráckeve and the $14^{\text {th }}$ century one from Dunaföldvár (TóTH 2013: 1-2).
${ }^{19}$ VAN DER MOORTEL 1991: 42; HutCHINSON 1995: 8, 11 , 18-19, 224-225; EllMERs 2001: 440, POMEY-REITH 2005: 29.

${ }^{20}$ PoMeY-ReITH 2005: 9.

${ }^{21}$ То́тн 2006: 61-66; То́тн 2010: 871-883. 
no more than brief mentions. Some technical data were made available for the logboats found in the Tisza water catchment area, such as the ones from Berindan (Satu Mare county), Bocsig (Arad county), Cărăşeu (Satu Mare county), Galu (Neamţ county), Palanca (Prahova county), Timişoara (Timiş county), Tiszabecs (Hungary), and Zădăreni (Arad county). ${ }^{22}$

The Bizere vessel is particularly important because to date it represents the only archaeological evidence of boats navigating on the Mureş river during the Middle Ages (12 $2^{\text {th }}$ century). This situation is due to the fact that none of the archaeologically known logboats from the area had a reliable context of discovery. The dugout technique cannot be used for establishing an evolutionary typology and in the absence of radiocarbon or dendrochronological analysis no clear-cut dating can be established. ${ }^{23}$ For this reason, previous typologies were based on morphology and construction techniques. ${ }^{24}$ For the boat under discussion the incomplete retrieval of the bottom made it impossible to obtain a clear cross-section. One can thus only assume that it belongs to the D- $0-C$ type defined by Beat Arnold..$^{25}$

However, a few remarks on the dimensions of the vessel can be made. It appears to be one of the largest watercrafts discovered in the area, similar to those from Berindan, ${ }^{26}$ Bocsig $^{27}$ and Zădăreni which are, respectively, 13.10, 13.00 and $11.20 \mathrm{~m}$ long. The dugout boat from Palanca is of similar length $(10.35 \mathrm{~m}),{ }^{28}$ as are some Early Modern Period vessels from Barcs ${ }^{29}$ and Tiszabecs ${ }^{30}$ in Hungary, measuring 11.35 and $12.35 \mathrm{~m}$. In the Czech territory an over $10 \mathrm{~m}$ long, presumably medieval boat was discovered at Přerov nad Labem (Bohemia). ${ }^{31}$

From a contextual point of view a short review of medieval boat finds in the Carpathian Basin reveals an analogy with Banatsko Aranđelovo (HU: Oroszlános), in present-day Serbia, near the confluence of the Tisza and Mureş rivers. Early $20^{\text {th }}$ century archaeological research conducted at a medieval eastern orthodox monastery (subsequently taken over by the Benedictine order) identified the remains of a boat at the perimeter of the site. ${ }^{32}$ The similarities between the two contexts of discovery are obvious. In both cases the location of the abbey justifies the need for such amenity.

Good comparison can be made with early inland navigation techniques on the Oder river (Poland) during the $12^{\text {th }}-13^{\text {th }}$ century. The area was a territory that hosted Cistercian monasteries (Lubiąż/Leubus, Trzebnicy/Trebnitz) with notable privileges in herring and salt transportation from Pomerania. Large logboats constitute the majority of watercraft finds ${ }^{33}$. The region even benefits from three lots of boat-shaped miniatures, of which the great

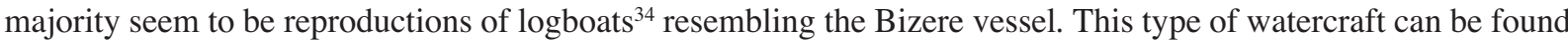
even in areas where there is certain evidence of large shipbuilding sites that assembled composite boats such as the one found at Wolin (Poland). ${ }^{35}$

Even though the artefact under discussion here is thus far a singular example in the territory of present-day Romania, previous comparisons lead one to conclude that this type of vessel was widely dispersed and had no set chronological frame. The reduced height of the sidewalls (as much as they were preserved) indicates a boat suitable for inland navigation, often recorded in archival documents.

\section{INLAND NAVIGATION AND THE USE OF THE BIZERE BOAT}

The first written source mentioning the existence of logboats on the Lower Danube states that in 1148 they were used by the Byzantines to cross the river and fight the Cumans. ${ }^{36}$ In the same region, a 1445 account on the war preparations of the Christian armies for the siege of Silistra, Turnu and Giurgiu (Wallachia) under Ottoman occupation, mentions a large number of dugout boats: 'Et promist ledit seigneur des Vallaques que, pour conduire

22 IURAŞCIUC 1967: 57-58; CHELCEA 1968: 362-366; BOTZAN 1990: 14-15; FLOREA 2002: 181; LiCHIADOPOL 2007-2008: 141-146.

${ }^{23}$ MCGrail-Switsur 1979: 230; HutChinson 1994: 12; ARNOLD 1995a: 15-19; PAZDUR et al. 2001: 403.

${ }^{24}$ ARNOLD 1995b: 7-9.

${ }^{25}$ ARNOLD 1995b: 12.

${ }^{26}$ IURAŞCIUC 1967: 57-58, fig. 1-2; CHELCEA 1968: $362-$ 363; BOTZAN 1990: 14.

${ }^{27}$ BotZAN 1990: 15.

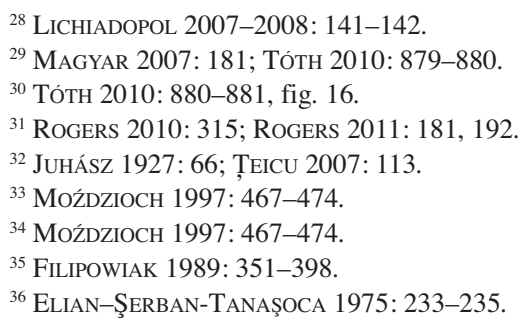


les gallees parmy la riviere, il bailleroit quarante ou chinquante bateaux, appelez manocques, qui sont d'une pieche, comme ung nocq a pourceaulz, longz et estrois, et beaucoup Vallaques dedens, en l'un plus, en l'autre moins'. ${ }^{37}$

For the Mureş Valley area the written documents are less precise when it comes to naming the ships, however the Bizere boat could be one of those so-called naves, recurring in $12^{\text {th }}$ and $13^{\text {th }}$ century charters. The Latin name is a general one and leaves no space for interpretation on the indigenous appellation. It could have been a strictly local term, specific for the Mureş area, or it may have varied given the multicultural milieu of the monasteries found here.

Most certainly the ships of the abbey were mentioned carrying salt on the Mureş in the year $1183 .{ }^{38}$ Through association with the charters regarding other monastic sites found nearby, one can assume that this phenomenon must have predated the first written record still preserved. In 1138 the obligation of the inhabitants of Şeitin (Arad county), connected to the salt revenues of the Dömös abbey (Hungary), was already set. The rafters were tasked with making six salt transports per year using two ships. ${ }^{39}$

The charter from 1183 states the salt privileges of the bishopric seat of Nitra, following an example previously set for Bizere abbey - 'Preterea tres naves saliferas ea libertate, quam habent naves Monasteri de Bisra in emendo et deferendo sale, sive Orodini, sive in Ciggedin servari placuerit ${ }^{.}{ }^{40}$ This is a valuable source as it proves that the monastery owned, at the time, several watercrafts with a clearly defined function: salt transportation.

Several attempts were made to differentiate between various types of medieval vessels. Most of them were based on a charter issued by King Andrew II, which provided data on three categories of ships navigating along the Mureş river ${ }^{41}$ The variations seem to have been defined by their hauling capacity. Unfortunately, when reconfirming this particular privilege, the 1289 document by King Ladislaus IV merely restates the previous classification without adding further details, except for the amounts of tolls to be collected for each type of boat ('de qualibet carina seu nave magna dimidiam marcam, de mediocri vero vel parva unum fertonem'). ${ }^{42}$ Without any specific data, one is as yet unable to tell what the larger ship - carina - looked like. The use of a special term may suggest some differences from the highly invocated rafts or logboats, as well as a variation of boats based not only on hauling capacity but also on morphological traits. It thus becomes obvious that one cannot simply understand the medieval watercrafts on the Mureş river by emphasising the great importance of primitive rafts $^{43}$ and logboats. However, vessels such as the analysed one were essential for local or micro-regional transhipment purposes, as it would be logical to assume that the functioning of a toll-collection point, implied managing and redirecting the salt raised as passing fee.

Nevertheless, it can be assumed that this was one of the transportation modes used for spreading the rich material culture found at sites such as Bizere. Thus, the watercrafts were not only used for salt transport, which tends to be overstated compared to other types of merchandise because of frequent reference in the archival record. For example, under the reign of Ladislaus IV boats are recorded as descending on the Someş River (north-western Romania) while carrying lime (caementum) and other construction material. ${ }^{44}$ This is the only written extant proof referring to the often overlooked matter of building material transportation. One cannot imagine the evolution of habitats such as Bizere abbey without the use of vessels for supplying the building sites. Studies across Europe have shown that large logboats were suitable for transport between the quarries and the construction sites. ${ }^{45}$

Except for these assumed functions, the present dugout vessel could have been used for strictly local activities, such as the transportation of people and goods across the river channels. Nevertheless, primitive watercrafts were used for fishing purposes. This situation can be imagined for the Bizere abbey, as, judging by its location, it is only natural to believe that the food resources at hand were made good use of. Some types of archaeological

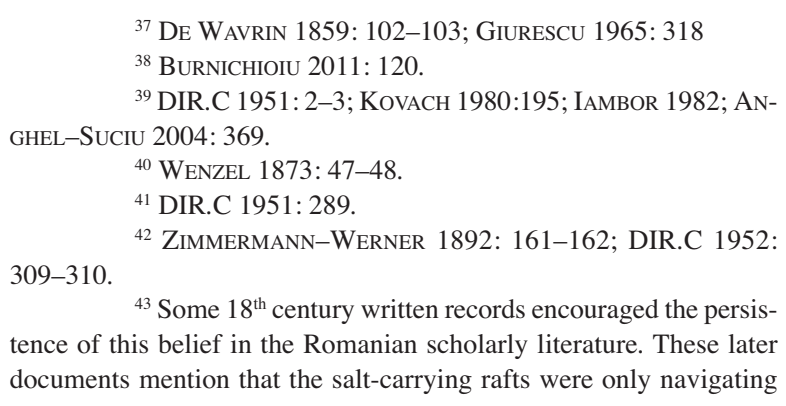

downstream, then disassembled and their timber was sold at the transhipment points (ANGHEL-SUCIU 2004: 373). However, some of the vessels were more elaborate than this, in which case there was sufficient reason to put in effort for upstream navigation. Indisputable proof for this practice can be also related to the Bizere monastery, as in 1230 a new charter was issued following the example of Bizere, recording two-way navigation on the Mureş water course (WENZEL 1873: 220; DIR.C 1951: 241-242).

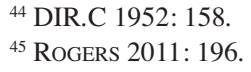

${ }^{44}$ DIR.C 1952: 158

${ }^{45}$ ROGERS 2011: 196. 
material retrieved from the site stand as evidence for this kind of activity: the fish bones and scales and the iron fishing hooks. ${ }^{46}$ It remains uncertain whether fishing was done with the aid of a rather large boat (like this one), or not, as smaller logboats are thought of as more suitable for this kind of activity, because they are easier to steer. ${ }^{47}$

As for the change in the boat's use, one can conclude that it took place mainly as a result of its decay, because the mixing of lime and mortar could have been done using less costly or sophisticated installations. Therefore sacrificing a perfectly good boat would have made no sense. This change of function is not an isolated phenomenon. Similar examples, related to the reuse of damaged watercrafts, exist elsewhere in Europe. Planking fragments from two boats were used for building a revetment on the bank of river Don (Doncaster, United Kingdom). ${ }^{48}$ Another boat was reused in a workshop from the artisans' quarter at the shipbuilding site at Wolin. ${ }^{49}$ In all three cases one encounters basic ways of use or 'recycling' for pragmatic reasons.

\section{CONCLUSIONS}

The find presented in this study stands out as a unique example because of its preservation and dating. The research conditions allowed the documentation of its context and the retrieval of valuable data for the first dating of such an artefact from Romania. Despite its singular context, its association to the monastic site is to be expected. The find perfectly fits the economic environment of the region, as indicated by medieval archival sources, and the local topography - an island location which commended the equipping of the monastery with the necessary means of communication for a good connection with its surroundings.

\section{AKNOWLEDGEMENTS}

This work was made possible through the financial support of a grant of the Romanian National Authority for Scientific Research, CNCS - UEFISCDI, project number PN-II-RU-TE-2012-3-0477.

\section{REFERENCES}

ALLEN et al. 2005

ANGHEL-SUCIU 2004

ARNOLD 1995a

Arnold 1995b

BINDING-NUSSBAUM 1978

BOTZAN 1990

BURNICHIOIU 2011

BURNICHIOIU-RUSU 2011

Chelcea 1968

DIR.C 1951

DIR.C 1952
= S. J. Allen-D. M. GoodbuRn-J. M. McComish-P. W. Rogers: Reused boat planking from a $13^{\text {th }}$ century revetment in Doncaster South Yorkshire. MedArch 49 (2005) 281-304.

= GH. ANGHEL-V. SuCIU: Mărturii ale practicării plutăritului în Transilvania din antichitate, evul mediu şi perioada modernă. Rolul oraşului Alba Iulia în istoria plutăritului [Zeugnisse der Ausübung des Flößens in Siebenbürgen im Altertum, in Mittelalter und in der frühen Neuzeit. Die Bedeutung der Stadt Alba Iulia (Karlsburg) für die Geschichte des Flößens]. Apulum 40 (2004) 367-386.

$=\mathrm{B}$. Arnold: Pirogues monoxyles d'Europe centrale: construction, typologie, évolution. 1. Archéologie Neuchâteliose 20. Neuchâtel 1995.

$=$ B. ARNOLD: Pirogues monoxyles d'Europe centrale: construction, typologie, évolution. 2. Archéologie Neuchâteliose 21. Neuchâtel 1995.

= G. BINDING-N. NussBaum: Der mittelalterliche Baubetrieb nördlich der Alpen in zeitgenössischen Darstelungen. Darmstadt 1978.

= M. BotZAN: Drumuri de apă [Waterways]. București 1990.

= I. BuRNichioIU: Cronologia abaţiei Bizere. Bizere abbey: a chronology. In: Mănăstirea Bizere. I. Eds A. A. Rusu, I. Burnichioiu. Cluj-Napoca 2011, 119-128.

= I. BuRnichioIU-A. A. Rusu: Medieval floor mosaics at Bizere Monastery. A brief survey. Transylvanian Review 20/2 (2011) 3-13.

= I. CHELCEA: Luntrele monoxile la noi [Logboats]. RMuz 5/4 (1968) 362-366.

$=$ Documente privind istoria României [Documents Regarding the History of Romania]. C. Transilvania. Veacul: XI, XII şi XIII. I (1075-1250). Bucureşti 1951.

$=$ Documente privind istoria României [Documents Regarding the History of Romania]. C. Transilvania. Veacul XIII. II (1251-1300). Bucureşti 1952.

\footnotetext{
${ }^{46}$ Stored at the CMA under inv. no. 17485 a-c.

${ }^{47}$ Rogers 2011: 196.
}

${ }^{48}$ ALLEN et al. 2005: 282.

${ }^{49}$ FiliPOWIAK 1989: 363, 388, Abb. 27. 
ELLMERS 2001

ELIAN-ŞERBAN-TANAŞOCA 1975

FILIPOWIAK 1989

FLOREA 2002

GIURESCU 1965

HUTCHINSON 1994

IAMBOR 1982

IONIȚ Ă 2009

IURAŞCIUC 1967

JUHÁSZ 1927

KovaCH 1980

LICHIADOPOL 2007-2008

MagYar 2007

MCGRAIL-SwITSUR 1979

MCGRAIL 1981

VAN DER MOORTEL 1988

\section{MoźDZIOCH 1997}

OssOWSKI 2010

PAZDUR-KRĄIEC-

MICHCZYŃSKI-OsSOWSKI 2001

POMEY-REITH 2005

RÉTHY 1899

RUSU-MARTA 2002

Rusu 2011a

Rusu 2011b

ROGERS 2010

ROGERS 2011
= D. Ellmers: Shipbuilding. In: Medieval Archaeology: an Encyclopaedia. Ed. P. J. Crabtree. New York-London 2001, 437-443.

= A. ELIAN-N. ŞERBAN-TANAŞOCA (eds): Fontes historiae daco-romanae. III: Scriitori bizantini (sec. XI-XIV) [Fontes historiae daco-romanae. III: Byzantine writers]. Bucureşti 1975.

= W. FILIPOWIAK: Die Häfen unde der Schifbau an der Odermündung im 9.-12. Jahrhundert. In: Untersuchungen zu Handel und Verker der vor- und frühgeschichtlichen Zeit in Mittel- und Nordeuropa. V.: Verkehr, Verkehrswege, Verkehrsmittel, Organisation. Hrsg. von H. Jankuhn, W. Kimmig, E. Ebel. Göttingen 1989, 351-398.

= P. M. FlOREA: Transporturile în Ţara Românească (secolul XIV-XIX) [The Transportation of Walachia $\left(14^{\text {th }}-19^{\text {th }}\right.$ centuries $\left.)\right]$. Bucureşti 2002

= C. C. GIURESCU: Construcţii navale în Principatele Române în secolele al XVII-lea şi al XVIII-lea [Shipbuilding in the Romanian Principalities during the $17^{\text {th }}$ and the $18^{\text {th }}$ centuries]. In: Omagiu lui P. Constantinescu-Iaşi cu prilejul împlinirii a 70 de ani. Eds E. Condurachi, G. Cogniot, P. Reiman and S. Stoian. Bucureşti 1965, 317-329.

= G. Hutchinson: Medieval Ships and Shipping. London 1994.

= P. IAMBOR: Drumuri şi vămi ale sării din Transilvania în perioada feudalismului timpuriu [Salt routes and toll-collection points form Transylvania during the early feudal period]. ActaMN 19 (1982) $75-85$.

= A. IonIȚ Ă: Aşezarea din secolele XII-XIII de la Bratei [The $12^{\text {th }}-13^{\text {th }}$ Centuries Settlement from Bratei]. Alba Iulia 2009

= I. IURAŞCIUC: O monoxilă neobişnuită [An unusual logboat]. RMuz 4/1 (1967) 57-58.

= K. JuHÁsz: Die Stifte zur Tscanader Dioceze im Mittelalter. Ein Beitrag zur Frühgeschichte und Kulturgeschichte des Banats. Münster 1927.

= G. Kovach: Date cu privire la transportul sării pe Mureş în secolele X-XIII [Data on the Mureş River salt transportation during the $10^{\text {th }}-13^{\text {th }}$ centuries]. Ziridava 12 (1980) 193-200.

= D. LichiAdOPOL: Monoxila de la Palanca - Râfov, jud. Prahova [The logboat from Palanca - Râfov, Prahova county]. Anuarul Muzeului de Istorie şi Arheologie Prahova. Studii şi cercetări. Serie Nouă 3-4 (11-12) (2007-2008) 141-146.

= K. MAGYAR: A középkori barcsi bödönhajó feltárása és kormeghatároyása [Excavation and age determination of a medieval logboat near Barcs]. In: Az erdő és a fa régészete és néprajza. Ed.: J. Gömöri. Sopron 2007, 179-187.

= S. McGraiL-R. Switsur: Medieval Logboats. MedArch 23 (1979) 229-231.

= S. McGrail: A Medieval logboat from the R. Calder at Stanley Ferry, Wakefield, Yorkshire. MedArch 25 (1981) 160-164.

= A. VAN DER MoORTEL: The construction of a cog-like vessel in the Late Middle Ages. In: Carvel Construction Technique: Skeleton-first, Shell-first. Fifth International Symposium on Boat and Ship Archaeology, Amsterdam 1988. Eds. R. Reinder, P. Kees. Oxbow monograph 12. Oxford 1988, $42-46$.

= S. MoźDzIoch: Usum aquarum. Der Fluß im frühmittealterlichen Altag Schlesiens. In: Život v archeologii středověku. Eds. J. Kubková, J. Klápště, M. Ježek, P. Meduna et al. Praga 1997, 567-481.

= W. Ossowski: Przemiany w szkutnictwie rzecznym w Polsce. Studium archeologiczne. Gdańsk 2010 .

= A. PAZDUR-M. KRĄPIEC-A. MiChCZYŃSKI-W. OsSOWSKI: Radiocarbon and dendrochronological dating of logboats from Poland. Radiocarbon 43/2A (2001) 403-415.

= P. POMEY-E. ReITH: L'archéologie navale. Paris 2005.

= L. RÉTHY: Corpus nummorum Hungariae. I. Budapest 1899.

= A. A. Rusu-D. MARTA: Materialul arheologic. Vesela ceramică [Archaeological material. The ceramic tableware]. In: A. A. Rusu (ed.): Cetatea Oradea. Monografie arheologică. I: Zona palatului episcopal. Oradea 2002, 133-144.

= A. A. Rusu: Componente de arhitectură şi instalaţii utilitare. Turnul cu fântână [Architectural components and utilitarian installations. The water tower]. In: Mănăstirea Bizere. I. Eds A. A. Rusu, I. Burnichioiu. Cluj-Napoca 2011, 49-60.

= A. A. Rusu: Componente de arhitectură şi instalaţii utilitare. Cuptorul de pâine [Architectural components and utilitarian installations. The bread oven]. In: Mănăstirea Bizere. I. Eds A. A. Rusu, I. Burnichioiu. Cluj-Napoca 2011, 95-100.

= J. Rogers: Logboats from Bohemia and Moravia, Czech Republic. International Journal of Nautical Archaeology 39/2 (2010) 310-326.

= J. RoGERS: Czech logboats: early inland watercraft from Bohemia and Moravia. SPFFBUM 16 (2011) 171-202. 
RUTTKAY 1976

TóTH 2006

То́тн 2010

TóTH 2013

ȚEICU 2007

DE WAVRIN 1859

Wenzel 1873

ZIMMERMANN-WERNER 1892
= A. RutTKAY: Waffen und Reiterausrüstung des 9. bis zur ersten Hälfte des 14. Jahrhunderts in der Slowakei (II). S1A 24/2 (1976) 245-395.

= A. Tóтн: River archaeology - A new field of research. Archeometriai Mühely 1 (2006) 63-66.

= J. A. TóтH: Adatok a kora újkori közép-Duna-medencei hajók régészetéhez [Data on the archaeology of Early Modern Age ships in the Middle Danube Basin region]. In: A középkori és a kora újkor régészete Magyarországon - Archaeology of the Middle Ages and Early Modern Period in Hungary. Eds E. Benkő, Gy. Kovács. Budapest 2010, II, 871-883.

= A. TóтH: Medieval shipwreck from Ráckeve. Hungarian Archaeology Spring 2013 (2013) 1-2.

= D. TeICU: Geografia ecleziastică a Banatului medieval (Ecclesiastical Geography of Medieval Banat). Reşiţa 2007

= J. DE WaVRIN: Anchiennes croniques d'Engleterre. Dupont Edition 2. Paris 1859

= G. Wenzel (ed.): Codex diplomaticus Arpadianus continuatus. Árpádkori új okmánytár. 11. Budapest 1873.

= F. ZIMMERMANN-C.WERNER (Hrsg.): Urkundenbuch zur Geschichte der Deutschen in Siebenbürgen. Erster Band: 1191 bis 1342 . Hermannstadt 1892. 